\title{
Metastasectomy for Tumor-Infiltrating Lymphocytes: An Emerging Operative Indication in Surgical Oncology
}

\author{
Joseph G. Crompton, MD, $\mathrm{PhD}^{1}$, Nicholas Klemen, $\mathrm{MD}^{2}$, and Udai S. Kammula, $\mathrm{MD}^{3,4}$ \\ ${ }^{1}$ Department of Surgery, University of California Los Angeles, Los Angeles, CA; ${ }^{2}$ Department of Surgery, Yale University \\ School of Medicine, New Haven, CT; ${ }^{3}$ Division of Surgical Oncology, Department of Surgery, University of Pittsburgh \\ School of Medicine, University of Pittsburgh Cancer Institute, Pittsburgh, PA; ${ }^{4}$ UPMC Hillman Cancer Center, Pittsburgh, \\ PA
}

\begin{abstract}
Adoptive cell transfer (ACT) of tumor-infiltrating lymphocytes (TILs) is an emerging immunotherapy for metastatic cancer. Surgeons play a central role in ACT treatments by performing resection of tumors from which TILs are isolated. It is important that surgeons have familiarity with this emerging treatment method because it is increasingly performed for an expanding variety of solid tumors at institutions around the world. This report offers a brief introduction to ACT for cancer, highlights historical milestones in its development, and provides patient selection and operative considerations for surgeons called upon to perform metastasectomy for the purpose of isolating TILs.
\end{abstract}

\section{A NOVEL WAY TO FIGHT CANCER}

In addition to the conventional methods of treating cancer (surgery, chemotherapy, and radiation), a treatment called adoptive cell transfer (ACT) is emerging that relies on the natural capacity of the immune system to target and eliminate tumor cells. ${ }^{1}$ The infiltration of tumor with immune cells, particularly $\mathrm{T}$ lymphocytes (also called tumor-infiltrating lymphocytes [TILs]), has long been observed, and recent findings have shown TILs to be predictive of patient survival in multiple solid tumor histologies. $^{2-5}$ For example, the presence of $\mathrm{T}$ cells within metastatic tumors of colorectal origin can be a superior

(C) The Author(s) 2017. This article is an open access publication

First Received: 9 August 2017;

Published Online: 29 November 2017

U. S. Kammula, MD

e-mail: kammulaus@upmc.edu predictor of patient survival compared with the standard histopathologic methods currently used to stage colorectal cancer. 6,7

Although $\mathrm{T}$ cells have a natural capacity to target tumors, it is thought that TILs become dysfunctional with time and lose their ability to eradicate tumor in late stages of cancer. $^{8,9}$ To restore anti-tumor immunity, ACT first involves surgical resection of a tumor to isolate TILs from the tumor microenvironment. Next, TILs are expanded ex vivo with the $\mathrm{T}$ cell growth factor interleukin-2 (IL-2) 10,11 (Fig. 1). Before the TILs are adoptively transferred back into the patient, the existing immune system is transiently ablated with a lympho-depleting chemotherapy regimen that facilitates homeostatic responses favorable for engraftment and persistence of the transferred T cells. After transfer, TILs circulate throughout the body and traffic to distant tumor sites and tumor-draining lymph nodes, where they can mount an anti-cancer immune response.

With the exception of chemotherapy for germ cell tumors, few curative systemic therapies exist for adults with metastatic solid tumors. ${ }^{12}$ This has changed with the administration of immunotherapies such as high-dose-bolus interleukin-2, checkpoint blockade, and ACT.

In two recent studies of ACT using TILs, selected patients with advanced melanoma had a complete response rate of 22-24\% and an overall response rate (measured by Response Evaluation Criteria in Solid Tumors [RECIST]) exceeding $50 \% .^{13,14}$ Importantly, more than $90 \%$ of the patients with a complete response to ACT remained disease free longer than 5 years.

In this brief review, we highlight the history of ACT for cancer and describe the central role of the surgeon, both in the development of this therapeutic approach and in its current practice. We also suggest practical guidelines that 


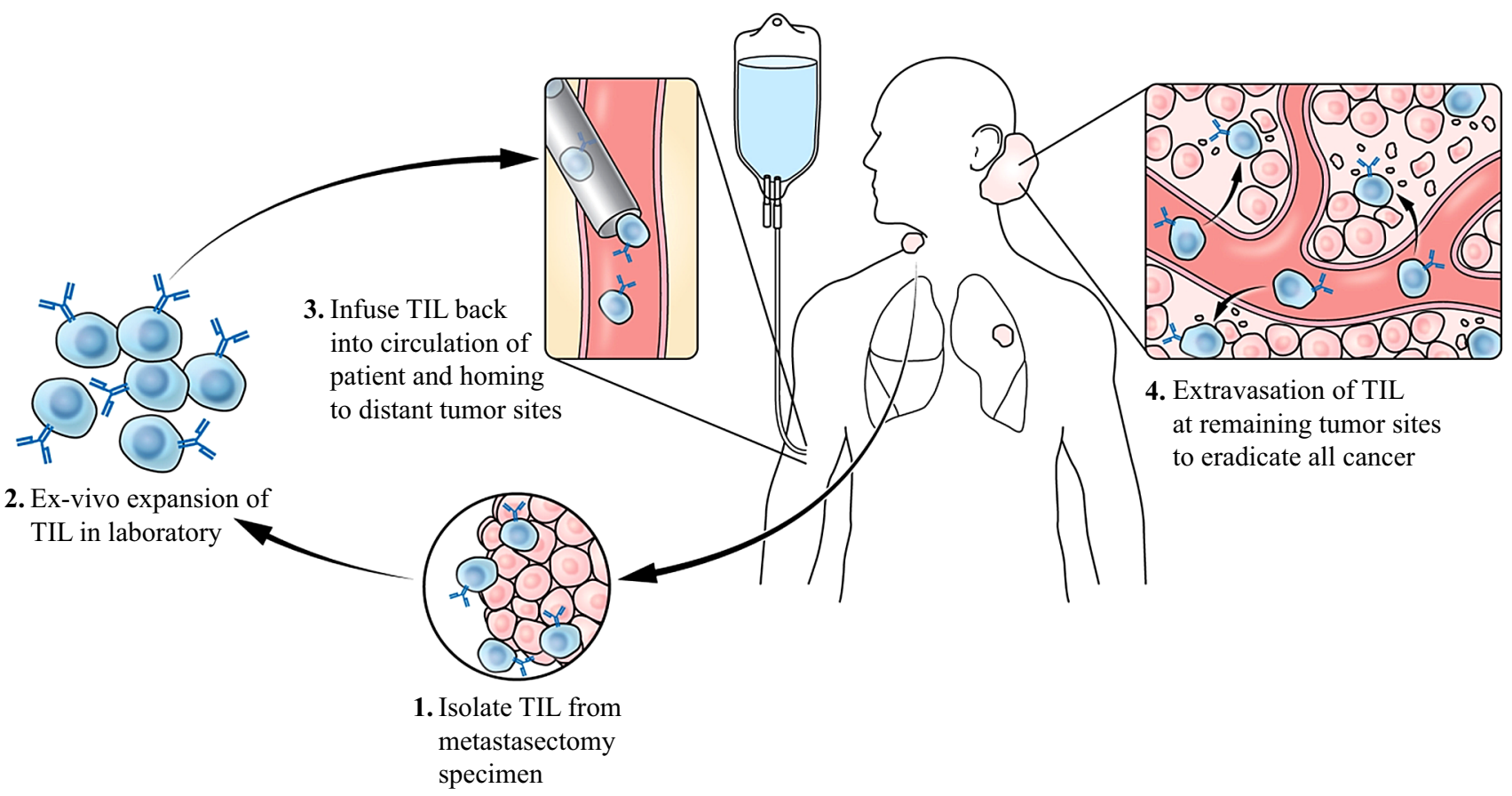

FIG. 1 Adoptive cell transfer (ACT) of tumor-infiltrating lymphocytes (TILs). A generalized model of ACT using TILs is summarized with the following critical steps: (1) performance of metastasectomy to isolate TILs, (2) expansion of TILs in the laboratory with

should be considered when a metastasectomy is performed to isolate TILs for the treatment of advanced cancer.

\section{A BRIEF HISTORY OF CELL-BASED IMMUNOTHERAPY}

Hence, it would seem fair to conclude that the lymphocyte is a necessary factor in cancer immunity

2 _ James B. Murphy and John J. Morton (January 1915).

Historically, surgeon-immunologists such as John Hunter (who mapped the lymphatic system) and William Coley (who observed tumor regression in sarcoma patients with acute bacterial infections) have played pioneering roles in the development of immunotherapy for patients with cancer. ${ }^{15}$ In 1915, when immunology was still in its infancy, surgeon John J. Morton showed that rejection of tumors in mice was associated with a local infiltration of lymphocytes, a particularly prescient finding because he also showed that irradiation prevented lymphocytic infiltration, thereby enabling tumors to grow. ${ }^{3,16}$ In 1964, the British surgeon E. J. Delorme was the first to show that adoptive transfer of lymphocytes in a mouse model could inhibit carcinogen-induced sarcoma growth. ${ }^{17}$ Collectively, these findings helped give form to the notion that lymphocytes may be used therapeutically to treat patients with advanced cancer. interleukin-2, (3) reinfusion of TILs after administration of lymphodepleting chemotherapy regimen (not shown), (4) TILs entering circulation and extravasating to tumor sites to eliminate malignant cells

A breakthrough came in the 1970s with the discovery of interleukin-2, which enabled in vitro culture of $\mathrm{T}$ lymphocytes. ${ }^{10,11}$ This paved the way for the modern era of cellular immunotherapy, which began in 1988 when surgeon Steven A. Rosenberg and colleagues first demonstrated that ACT of TILs could effectively treat patients with advanced melanoma in studies conducted at the Surgery Branch of the National Cancer Institute. ${ }^{18}$ In these studies, 20 patients with metastatic melanoma were treated with ACT, and cancer regression was observed in diverse metastatic sites including liver, bone, and skin. Subsequent studies showed that the efficacy of ACT could be significantly improved when a lympho-depleting regimen of chemotherapy was administered before cell transfer. ${ }^{19,20}$

Murine models of immunosuppression before $\mathrm{T}$ cell transfer have suggested several benefits, including transient elimination of endogenous regulatory populations (e.g., regulatory $\mathrm{T}$ cells and myeloid derived suppressor cells) and immune cells that do not have specificity for cancer. ${ }^{21}$ Furthermore, lympho-depletion can augment availability of homeostatic cytokines and growth factors to enhance the engraftment and function of the transferred TILs. Although ACT was pioneered in patients with metastatic cutaneous melanoma, recent evidence shows that this treatment strategy can be extended to other cancers. Adoptive transfer of TILs in patients with advanced uveal melanoma, 
previously considered to be immunotherapy-resistant and in patients with human papillomavirus (HPV)-associated epithelial cancers (including cervical and oropharyngeal cancer) resulted in objective response rates of 35 and 33\%, respectively. ${ }^{22,23}$ Case reports also show ACT resulting in partial responses of metastatic cholangiocarcinoma and colorectal cancer ${ }^{24,25}$ after infusion of selected $\mathrm{T}$ cells that recognized the gene products of mutated cancer genes (termed neoantigens). Clinical trials of TIL therapy for patients with a variety of solid tumors are actively accruing (Table 1).

\section{PATIENT SELECTION FOR ACT}

Typically, patients being considered for ACT have often progressed through a number of conventional therapies and present with advanced-stage disease and limited life expectancy. ${ }^{13}$ As a part of a multidisciplinary team, surgeons play an integral role in selecting patients for ACT and planning a surgical approach with minimal morbidity, thereby ensuring that patients can be treated in a timely manner.

Eligible candidates for ACT should demonstrate adequate performance status (Eastern Cooperative Oncology Group [ECOG] 0 or 1). A commonly used lymphodepleting regimen includes cyclophosphamide $(60 \mathrm{mg} / \mathrm{kg})$ and fludarabine $\left(25 \mathrm{mg} / \mathrm{m}^{2}\right)$, which results in transient neutropenia for approximately 6-10 days, during which patients are vulnerable to septic complications (Table 2). Thus, treatment of patients at high risk for bacterial infections, such as those with biliary obstruction, chronic cholangitis, or indwelling biliary or ureteral stents, is relatively contraindicated. Lympho-depletion may further exacerbate chronic viral infections such as hepatitis $\mathrm{C}$, hepatitis B, and human immunodeficiency virus. However, data are minimal on the outcomes for such patients after this type of preparative regimen. Transient thrombocytopenia also is common, so bleeding risk (e.g., from gastrointestinal or brain metastases) should be assessed before therapy.

Many ACT protocols administer high-dose-bolus intravenous IL-2 with cell transfer because it is thought to promote in vivo persistence and effector function of TILs. The administration of IL-2 can induce progressive capillary leak syndrome, which may cause respiratory compromise. $^{26,27}$ Thus, eligible patients should have sufficient cardiopulmonary and renal reserve to tolerate the treatment.

Pregnancy is an absolute contraindication for ACT given the inherent risks to both the mother and the fetus. Small asymptomatic brain metastases are not a contraindication for ACT because durable regression of such lesions has been observed. ${ }^{28}$ However, symptomatic brain metastases, lesions larger than $1 \mathrm{~cm}$, and edema or active bleeding should be managed before cell therapy to minimize neurologic complications. In the setting of primary autoimmune disorders requiring immunosuppression, ACT is contraindicated because of the suppressive effects on the transferred $\mathrm{T}$ cells (Table 2). Although checkpoint inhibitors (including anti-CTLA-4 and anti-PD-1 antibodies) have been associated with severe autoimmune side effects (including colitis, pneumonitis, and irreversible hypophysitis), these types of adverse events are rarely seen with TIL therapy.

Although no evidence exists to show that extensive tumor bulk directly impedes the efficacy of ACT, patients with extensive and rapidly progressive tumor burden often have limited time to wait for the manufacturing of a TIL product. Nonetheless, when appropriately timed, ACT can have a therapeutic impact on the most highly advanced patients. To illustrate this point, we present the case of a 52-year-old woman with significant metastatic burden from uveal melanoma, an orphan disease refractory to all conventional systemic treatments including immune checkpoint inhibitors. ${ }^{23}$ The patient presented with extensive bone, liver, peritoneal, and omental metastases, as demonstrated by positron emission tomography (PET) imaging (Fig. 2). After ACT using tumor reactive TILs, she demonstrated a dramatic and rapid regression of her disease burden associated with symptomatic relief from pain and early satiety.

\section{OPERATIVE CONSIDERATIONS FOR TIL METASTASECTOMY}

After patient selection, the next major decision facing the surgeon is selection of a tumor for TIL harvest (Table 3). Although tumor size does not correlate with efficacy of TIL therapy, tumors should be at least $2 \mathrm{~cm}$ in largest diameter to ensure an adequate quantity of tissue for successful processing. Larger tumors may have hypoxic and necrotic centers and do not necessarily yield higher quantities of TILs.

No known correlation exists between the site of metastasectomy and the capacity to generate TILs. Cultures of TILs have been successfully initiated and expanded from diverse sites including liver, lymph node, lung, and gastrointestinal tract. ${ }^{29}$ Lymph nodes remain ideal sources of TILs because they can often be recovered with minimal postoperative morbidity. It should be cautioned that tumors procured from the lumen of the gastrointestinal (GI) tract or those that have occult colonization with bacteria or yeast often develop prohibitory contamination during ex vivo culture. An additional theoretical concern arises when TILs 
TABLE 1 Selected trials of adoptive cellular immunotherapy (ACT) with tumor-inflitrating lymphocytes (TILs) isolated by surgical metastasectomy ${ }^{\mathrm{a}}$

\begin{tabular}{|c|c|c|c|}
\hline Clinical trial & Summary & Cancer type(s) & Sponsor/collaborators \\
\hline NCT01807182 & $\begin{array}{l}\text { ACT of TILs after combination } \\
\text { chemotherapy }\end{array}$ & Melanoma & $\begin{array}{l}\text { Fred Hutchinson Cancer Research Center; National } \\
\text { Cancer Institute (NCI) }\end{array}$ \\
\hline NCT02652455 & $\begin{array}{l}\text { ACT of TILs plus PD-1 blockade } \\
\text { and CD137 agonism }\end{array}$ & Melanoma & $\begin{array}{l}\text { H. Lee Moffitt Cancer Center and Research Institute; } \\
\text { Bristol-Myers Squibb; Prometheus Inc.; Iovance } \\
\text { Biotherapeutics, Inc. }\end{array}$ \\
\hline NCT00604136 & ACT of TILs & Melanoma & Hadassah Medical Organization \\
\hline NCT02354690 & ACT of TILs plus vemurafenib & Melanoma & Inge Marie Svane; Herlev Hospital \\
\hline NCT02379195 & ACT of TILs plus peginterferon & Melanoma & Inge Marie Svane; Herlev Hospital \\
\hline NCT02926053 & ACT of TILs & Renal cell carcinoma & Inge Marie Svane; Herlev Hospital \\
\hline NCT02360579 & ACT of TILs & Melanoma & Iovance Biotherapeutics, Inc. \\
\hline NCT03083873 & ACT of TILs & $\begin{array}{l}\text { Squamous cell carcinoma of head } \\
\text { and neck }\end{array}$ & Iovance Biotherapeutics, Inc. \\
\hline NCT03108495 & ACT of TILs & Cervical carcinoma & Iovance Biotherapeutics, Inc. \\
\hline NCT01946373 & $\begin{array}{l}\text { ACT with or without dendritic } \\
\text { cell vaccination }\end{array}$ & Melanoma & Karolinska University Hospital \\
\hline NCT01955460 & $\begin{array}{l}\text { ACT with TGF-beta-resistant } \\
\text { (DNRII) and NGFR- } \\
\text { transduced T cells }\end{array}$ & Melanoma & $\begin{array}{l}\text { M.D. Anderson Cancer Center; Cancer Prevention } \\
\text { Research Institute of Texas }\end{array}$ \\
\hline NCT01740557 & $\begin{array}{l}\text { ACT with T cells transduced } \\
\text { with CXCR2 and NGFR }\end{array}$ & Melanoma & $\begin{array}{l}\text { M.D. Anderson Cancer Center; National Cancer } \\
\text { Institute (NIH/NCI); Prometheus Laboratories; Key } \\
\text { Biologics, LLC }\end{array}$ \\
\hline NCT00338377 & $\begin{array}{l}\text { ACT with or without dendritic } \\
\text { cell immunization }\end{array}$ & Melanoma & $\begin{array}{l}\text { M.D. Anderson Cancer Center; Prometheus } \\
\text { Laboratories; Key Biologics, LLC; National Cancer } \\
\text { Institute (NCI); Adelson Medical Research }\end{array}$ \\
\hline NCT01174121 & ACT of TILs & $\begin{array}{l}\text { Gastrointestinal carcinoma, } \\
\text { metastatic (colorectal, gastric, } \\
\text { pancreatic, cholangio, } \\
\text { hepatocellular) }\end{array}$ & $\begin{array}{l}\text { National Cancer Institute (NCI); National Institutes of } \\
\text { Health Clinical Center (CC) }\end{array}$ \\
\hline NCT01993719 & ACT of TILs & Melanoma & $\begin{array}{l}\text { National Cancer Institute (NCI); National Institutes of } \\
\text { Health Clinical Center (CC) }\end{array}$ \\
\hline NCT02621021 & $\begin{array}{l}\text { Prospective randomized phase } 2 \\
\text { trial of TILs plus IL-2, alone } \\
\text { or after pembrolizumab }\end{array}$ & Melanoma & $\begin{array}{l}\text { National Cancer Institute (NCI); National Institutes of } \\
\text { Health Clinical Center (CC) }\end{array}$ \\
\hline NCT02650986 & $\begin{array}{l}\text { ACT of TGFbDNRII-transduced } \\
\text { TIL plus NY-ESO-1 reactive } \\
\text { TCR transduced PBL }\end{array}$ & Solid tumors expressing NY-ESO-1 & $\begin{array}{l}\text { Roswell Park Cancer Institute; National Cancer } \\
\text { Institute (NCI) }\end{array}$ \\
\hline NCT03166397 & ACT of TIL & Melanoma & Sheba Medical Center \\
\hline NCT02421640 & ACT of TIL following CCR & Nasopharyngeal carcinoma & Sun Yat-sen University \\
\hline NCT02278887 & ACT of TIL versus Ipilimumab & Melanoma & $\begin{array}{l}\text { The Netherlands Cancer Institute; Copenhagen } \\
\text { University Hospital at Herlev; University of } \\
\text { Manchester }\end{array}$ \\
\hline NCT01883297 & $\begin{array}{l}\text { ACT of re-stimulated TIL plus } \\
\text { low-dose IL-2 }\end{array}$ & $\begin{array}{l}\text { Ovarian, fallopian or peritoneal } \\
\text { cancer }\end{array}$ & University Health Network, Toronto \\
\hline NCT01883323 & ACT of TIL plus low-dose IL-2 & Melanoma & University Health Network, Toronto \\
\hline NCT02414945 & ACT of TIL plus low-dose IL-2 & Pleural mesothelioma & University Health Network, Toronto \\
\hline NCT03158935 & $\begin{array}{l}\text { ACT of TIL followed by } \\
\text { Pembrolizumab }\end{array}$ & Ovarian cancer; melanoma & $\begin{array}{l}\text { University Health Network, Toronto; Merck Sharp \& } \\
\text { Dohme Corp. }\end{array}$ \\
\hline
\end{tabular}

$T G F$ transforming growth factor, NGFR nerve growth factor receptor

${ }^{a}$ Additional details of each trial can be found by searching trial number at https://clinicaltrials.gov/

are isolated from lymphoid-rich tissues including the spleen or bowel (Table 3). Bystander $\mathrm{T}$ cells from these sites may expand ex vivo but will lack anti-tumor immune specificity. Thus, it is essential to confirm the presence and 
TABLE 2 Patient selection for adoptive cell transfer (ACT) immunotherapy

\begin{tabular}{|c|c|}
\hline \multirow{5}{*}{$\begin{array}{l}\text { Relative } \\
\quad \text { contraindications }\end{array}$} & Age $<18$ or $>70$ years \\
\hline & ECOG performance status $>1$ \\
\hline & Unacceptable risk of sepsis or bleeding during 7-10 days of neutropenia and thrombocytopenia \\
\hline & $\begin{array}{l}\text { Inability to tolerate interleukin-2 administration due to cardiopulmonary or renal insufficiency (some ACT protocols use } \\
\text { low-dose or no IL-2) }\end{array}$ \\
\hline & Current treatment with corticosteroids or immunosuppressive agents \\
\hline \multirow{2}{*}{$\begin{array}{l}\text { Absolute } \\
\text { contraindications }\end{array}$} & Primary immunodeficiency or chronic viral disease (e.g., HIV, HBV, HCV) \\
\hline & Pregnancy \\
\hline \multirow[t]{3}{*}{ Other considerations } & Large, symptomatic, or bleeding CNS lesions should be treated before ACT. \\
\hline & $\begin{array}{l}\text { Although trial eligibility may necessitate treatment with standard-of-care therapy before ACT, metastasectomy for TIL } \\
\text { harvest can be performed first and the T cells frozen for later use. }\end{array}$ \\
\hline & Patients in trials may require a radiographically evaluable target lesion for measurement of response to ACT. \\
\hline
\end{tabular}

ECOG Eastern Cooperative Oncology Group, $H I V$ human immunodeficiency virus, $H B V$ hepatitis B virus, $H C V$ hepatitis $\mathrm{C}$ virus, $C N S$ central nervous system, TIL tumor-infiltrating lymphocyte

FIG. 2 Regression of metastatic uveal melanoma after adoptive cell transfer. Example of rapid clinical response in a 52-year-old woman with metastatic uveal melanoma after adoptive cell transfer (ACT) of tumor-infiltrating lymphocytes (TILs). Pre-therapy and sequential post-therapy positron emission tomography (PET) scan images are shown, which demonstrate the partial regression by Response Evaluation Criteria in Solid Tumors (RECIST) of multiple peritoneal (Per), omental (Om), liver (Liv), and bone (Bo) metastases. *Normal physiologic 2-deoxy-2[fluorine-18] fluoro-D-glucose (18F-FDG) uptake in the heart
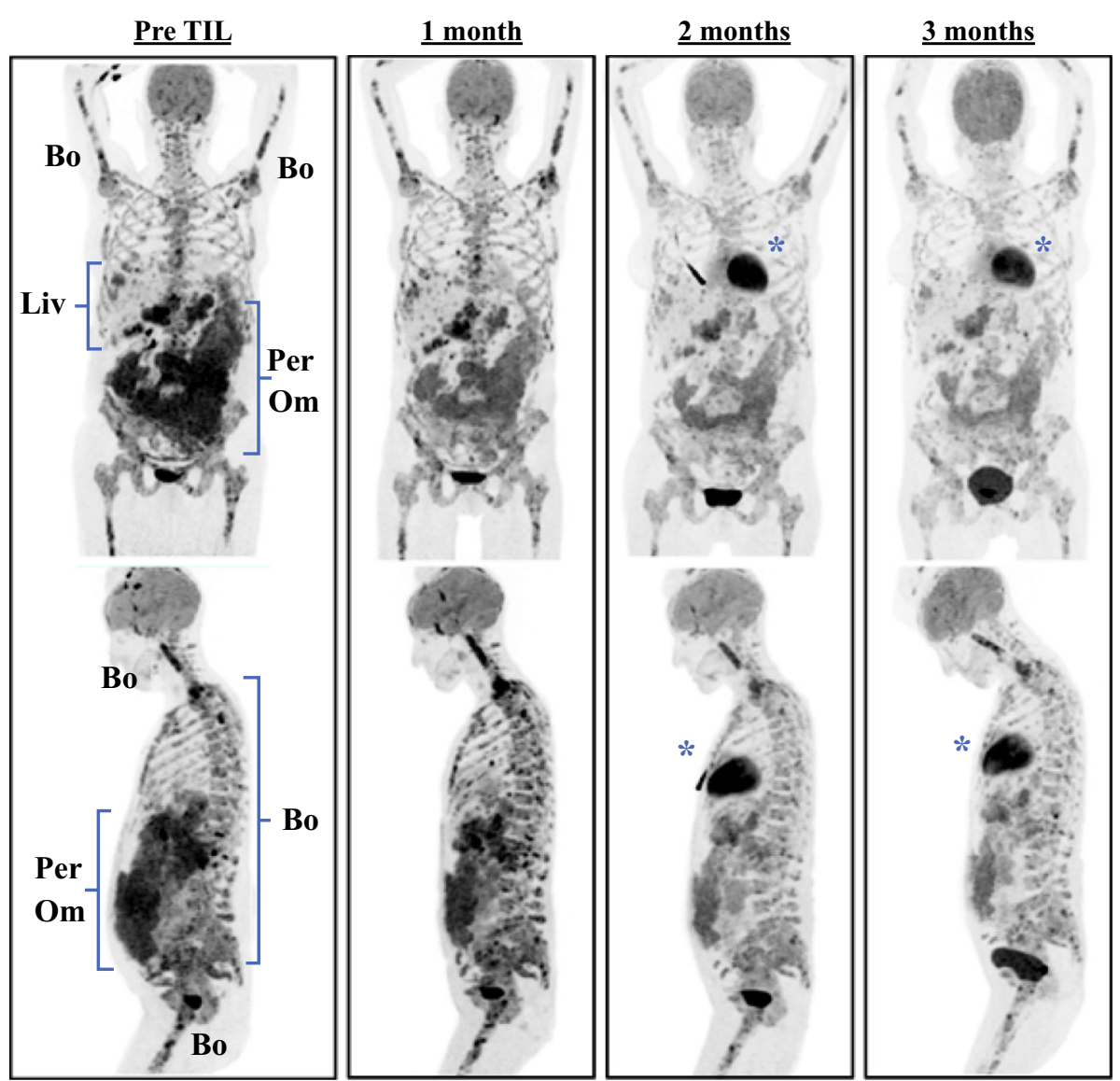

extent of tumor involvement when procuring lymphoid tissues.

Resection of visceral tumors can often be performed with a minimally invasive approach, as described in a series of 22 patients with stage M1c melanoma who underwent laparoscopic liver resection to procure tumor tissue for TIL generation. ${ }^{30}$ For many patients with widely metastatic disease, resection of metastases for TIL therapy does not demand wide surgical margins or major organ resection typically used for curative procedures (Table 3 ).

Once excised, tumors should be kept on ice and immediately transferred to a laboratory with personnel trained to dissect the tumor and initiate cultures. After isolation and expansion from fresh tumors, TILs in single- 
TABLE 3 Operative considerations in isolating tumor-infiltrating lymphocytes (TILs)

\begin{tabular}{|c|c|}
\hline Consideration & Details \\
\hline Tumor size & $\begin{array}{l}\text { Tumor size does not correlate with TIL efficacy, but tumors should be at least } 2 \mathrm{~cm} \text { in largest diameter to obtain adequate yield } \\
\text { of tissue for processing. }\end{array}$ \\
\hline $\begin{array}{c}\text { Irradiated } \\
\text { tumors }\end{array}$ & Avoid harvesting TILs from a tumor site that has previously been irradiated. \\
\hline Tumor site & $\begin{array}{l}\text { Because TILs can be procured from a variety of tumor sites, favor surgical sites that result in minimal morbidity and consider } \\
\text { laparoscopic approach. }\end{array}$ \\
\hline Margins & $\begin{array}{l}\text { Wide surgical margins and major organ resection are not typically necessary unless the tumor resection is being performed for } \\
\text { curative intent. Avoid cutting through tumor to minimize risk of seeding tumor site. }\end{array}$ \\
\hline Wound healing & Avoid harvest of superficial lesions if wound healing may be compromised. \\
\hline Contamination & $\begin{array}{l}\text { Ulcerating tumors and those with high suspicion for bacterial colonization can result in contamination of cultures. Isolation of } \\
\text { TILs from bowel lesions is possible but may be associated with an increased risk of contamination. }\end{array}$ \\
\hline Splenic lesions & $\begin{array}{l}\text { Splenic tumors are not optimal for TILs because of theoretical concern that they may be enriched in bystander lymphocytes that } \\
\text { are not tumor-reactive. }\end{array}$ \\
\hline CNS lesions & Tumors metastatic to CNS have not been adequately assessed as a source of TILs for treatment. \\
\hline Harvest & Refer to institutional guidelines for instructions on handling, processing, and labeling of tumor specimens. \\
\hline Confirmation & $\begin{array}{l}\text { Confirmation that the metastasectomy specimen contains malignant cells will ensure that benign or nodal tissue has not been } \\
\text { inadvertently collected. }\end{array}$ \\
\hline
\end{tabular}

CNS central nervous system

cell suspension can be cryopreserved for delayed treatment. As a final consideration, patients in clinical trials often require the presence of at least one evaluable target lesion so that the response to therapy can be measured by standard oncologic criteria, such as RECIST.

\section{LIMITATIONS OF ACT}

Despite attempts to optimize patient selection, some patients may experience a decline in functional status after tumor procurement due to cancer progression or surgical complications to the point that they are no longer candidates for ACT. Furthermore, although experienced laboratories can routinely generate TIL cultures from metastatic tumors, in some circumstances, the harvested tumor fails to yield sufficient numbers of $\mathrm{T}$ cells for a treatment due to exhaustion of the $\mathrm{T}$ cells, lack of tumor reactivity, or culture contamination. ${ }^{31}$ Accumulation of these risks implies that a proportion of patients will undergo TIL harvest but ultimately will not be eligible for ACT. ${ }^{32}$ Patients should be counseled regarding this possibility.

\section{FUTURE RESEARCH DIRECTIONS}

In analyses of cutaneous melanoma patients who achieved durable and complete clinical responses after ACT, the infused TILs were found to immunologically recognize one or more neoantigens, the gene products of somatic mutations. ${ }^{33}$ These findings provide compelling evidence that tumor-specific mutations can generate neoepitopes that elicit robust autologous immunologic responses in cutaneous melanoma patients. In fact, the high mutational burden in cutaneous melanoma, largely driven by ultraviolet mutagenesis, may explain the susceptibility of this cancer to a variety of immunotherapeutic approaches. Consequently, other highly mutated cancers including non-small cell lung cancer, bladder cancers, and microsatellite-unstable GI cancers may represent additional cancers to be investigated with TIL therapy. It should be noted that these histologies have demonstrated favorable responses to immunotherapy using checkpoint inhibitors. 34,35

In an effort to target cancers with a low mutational burden, it may be possible to select or purify low-frequency $\mathrm{T}$ cell populations that possess neoantigen reactivity. ${ }^{24,25,36}$ Furthermore, preclinical data suggest that the efficacy of ACT is correlated with the differentiation status or "stemness" of transferred T cells. ${ }^{37,38}$ Methods to minimize differentiation during ex vivo expansion, manipulate $\mathrm{T}$ cell functional avidity, and enhance the metabolic fitness of $\mathrm{T}$ cells may further improve clinical outcomes. ${ }^{39-42}$ Finally, combinatorial treatments that couple ACT with immune-modulating agents, such as checkpoint inhibitors, also may improve efficacy. ${ }^{43}$

\section{CONCLUSIONS}

Adoptive cell transfer has shown early therapeutic promise for a variety of advanced solid cancers. Although 
initially limited to a few institutions, recent innovations have increased the feasibility and effectiveness of this treatment method, and it currently is offered at multiple cancer centers around the world. Treatment with ACT remains a relatively resource-intensive and costly therapy that requires large-scale institutional support and a full good manufacturing practice (GMP) laboratory. The challenge of making ACT more widely available may involve either commercialization or designated centers that can provide consulting, manufacturing, and regulatory support. Surgeons have played a pioneering role in the development of immunotherapy for cancer. Through their direct involvement with patients, the ability to procure tumors, and their unique insights into cancer biology, surgeons will continue to make important contributions that increase the safety and effectiveness of cell-based therapies.

\section{DISCLOSURE There are no conflicts of interest.}

OPEN ACCESS This article is distributed under the terms of the Creative Commons Attribution 4.0 International License (http:// creativecommons.org/licenses/by/4.0/), which permits unrestricted use, distribution, and reproduction in any medium, provided you give appropriate credit to the original author(s) and the source, provide a link to the Creative Commons license, and indicate if changes were made.

\section{REFERENCES}

1. Restifo NP, Dudley ME, Rosenberg SA. Adoptive immunotherapy for cancer: harnessing the T cell response. Nat Pub Group. 2012;12:269-81.

2. Murphy JB, Morton JJ. The lymphocyte as a factor in natural and induced resistance to transplanted cancer. Proc Natl Acad Sci USA. 1915;1:435-7.

3. Murphy JB, Morton JJ. The lymphocyte in natural and induced resistance to transplanted cancer: II. Studies in lymphoid activity. J Exp Med. 1915;22:204-11.

4. Ibrahim EM, Al-Foheidi ME, Al-Mansour MM, Kazkaz GA. The prognostic value of tumor-infiltrating lymphocytes in triple-negative breast cancer: a meta-analysis. Breast Cancer Res Treat. 2014;148:467-76.

5. Khan H, Pillarisetty VG, Katz SC. The prognostic value of liver tumor T cell infiltrates. J Surg Res. 2014;191:189-95.

6. Galon J, Costes A, Sanchez-Cabo F, Kirilovsky A, Mlecnik B, Lagorce-Pagès $C$, et al. Type, density, and location of immune cells within human colorectal tumors predict clinical outcome. Science. 2006;313:1960-4.

7. Galon J, Mlecnik B, Bindea G, Angell HK, Berger A, Lagorce C, et al. Towards the introduction of the "Immunoscore" in the classification of malignant tumours. J Pathol. 2013;232:199-209.

8. Bindea G, Mlecnik B, Tosolini M, Kirilovsky A, Waldner M, Obenauf AC, et al. Spatiotemporal dynamics of intratumoral immune cells reveal the immune landscape in human cancer. Immunity. 2013;39:782-95.

9. Baitsch L, Baumgaertner P, Devêvre E, Raghav SK, Legat A, Barba L, et al. Exhaustion of tumor-specific CD8 $+\mathrm{T}$ cells in metastases from melanoma patients. $J$ Clin Invest. 2011;121:2350-60.
10. Morgan DA, Ruscetti FW, Gallo R. Selective in vitro growth of T lymphocytes from normal human bone marrows. Science. 1976;193:1007-8.

11. Ruscetti FW, Morgan DA, Gallo RC. Functional and morphologic characterization of human $\mathrm{T}$ cells continuously grown in vitro. J Immunol. 1977;119:131-8.

12. Rosenberg SA. IL-2: the first effective immunotherapy for human cancer. J Immunol. 2014;192:5451-8.

13. Rosenberg SA, Yang JC, Sherry RM, Kammula US, Hughes MS, Phan GQ, et al. Durable complete responses in heavily pretreated patients with metastatic melanoma using T-cell transfer immunotherapy. Clin Cancer Res. 2011;17:4550-7.

14. Goff SL, Dudley ME, Citrin DE, Somerville RP, Wunderlich JR, Danforth DN, et al. Randomized, prospective evaluation comparing intensity of lymphodepletion before adoptive transfer of tumor-infiltrating lymphocytes for patients with metastatic melanoma. J Clin Oncol. 2016, 34(20):2389-2397.

15. Coley WB. II. Contribution to the knowledge of sarcoma. Ann Surg. 1891;14:199-220.

16. Murphy JB, Morton JJ. The effect of roentgen rays on the rate of growth of spontaneous tumors in mice. $J$ Exp Med. $1915 ; 22: 800-3$.

17. Delorme EJ, Alexander P. Treatment of primary fibrosarcoma in the rat with immune lymphocytes. Lancet. 1964;2:117-20.

18. Rosenberg SA, Packard BS, Aebersold PM. Use of tumor-infiltrating lymphocytes and interleukin-2 in the immunotherapy of patients with metastatic melanoma: a preliminary report. $N$ Engl $J$ Med. 1988;319:1676-80.

19. Dudley ME, Wunderlich JR, Yang JC, Sherry RM, Topalian SL, Restifo NP, et al. Adoptive cell transfer therapy following nonmyeloablative but lymphodepleting chemotherapy for the treatment of patients with refractory metastatic melanoma. $J$ Clin Oncol. 2005;23:2346-57.

20. Dudley ME, Wunderlich JR, Robbins PF, Yang JC, Hwu P, Schwartzentruber DJ, et al. Cancer regression and autoimmunity in patients after clonal repopulation with antitumor lymphocytes. Science. 2002;298:850-4.

21. Gattinoni L, Finkelstein SE, Klebanoff CA, Antony PA, Palmer DC, Spiess PJ, et al. Removal of homeostatic cytokine sinks by lymphodepletion enhances the efficacy of adoptively transferred tumor-specific CD8 + T cells. J Exp Med. 2005;202:907-12.

22. Stevanović S, Draper LM, Langhan MM, Campbell TE, Kwong ML, Wunderlich JR, et al. Complete regression of metastatic cervical cancer after treatment with human papillomavirus-targeted tumor-infiltrating T cells. J Clin Oncol. 2015;33:1543-50.

23. Chandran SS, Somerville R, Yang JC, Sherry RM. Treatment of metastatic uveal melanoma with adoptive transfer of tumour-infiltrating lymphocytes: a single-centre, two-stage, single-arm, phase 2 study. Lancet. 2017; 18(6):792-802.

24. Tran E, Turcotte S, Gros A, Robbins PF, Lu Y-C, Dudley ME, et al. Cancer immunotherapy based on mutation-specific $\mathrm{CD} 4+\mathrm{T}$ cells in a patient with epithelial cancer. Science. 2014;344:641-5.

25. Tran E, Robbins PF, Lu Y-C, Prickett TD, Gartner JJ, Jia L, et al. $\mathrm{T}$ cell transfer therapy targeting mutant KRAS in cancer. $N$ Engl J Med. 2016;375:2255-62.

26. Schwartzentruber DJ, Lawson DH, Richards JM, Conry RM, Miller DM, Treisman J, et al. gp100 peptide vaccine and interleukin-2 in patients with advanced melanoma. $N$ Engl $J$ Med. 2011;364:2119-27.

27. Atkins MB, Lotze MT, Dutcher JP, Fisher RI, Weiss G, Margolin $\mathrm{K}$, et al. High-dose recombinant interleukin 2 therapy for patients with metastatic melanoma: analysis of 270 patients treated between 1985 and 1993. J Clin Oncol. 1999;17:2105-16. 
28. Hong JJ, Rosenberg SA, Dudley ME, Yang JC, White DE, Butman JA, et al. Successful treatment of melanoma brain metastases with adoptive cell therapy. Clin Cancer Res. 2010;16:4892-98.

29. Goff SL, Smith FO, Klapper JA, Sherry R, Wunderlich JR, Steinberg SM, et al. Tumor-infiltrating lymphocyte therapy for metastatic melanoma: analysis of tumors resected for TIL. $J$ Immunother. 2010;33:840-47.

30. Alvarez-Downing MM, Inchauste SM, Dudley ME, White DE, Wunderlich JR, Rosenberg SA, et al. Minimally invasive liver resection to obtain tumor-infiltrating lymphocytes for adoptive cell therapy in patients with metastatic melanoma. World J Surg Oncol. 2012;10:113.

31. Singh N, Perazzelli J, Grupp SA, Barrett DM. Early memory phenotypes drive $\mathrm{T}$ cell proliferation in patients with pediatric malignancies. Sci Transl Med. 2016;8(320):320ra3.

32. Klapper JA, Davis JL, Ripley RT, Smith FO, Nguyen DM, Kwong KF, et al. Thoracic metastasectomy for adoptive immunotherapy of melanoma: a single-institution experience. $J$ Thorac Cardiovasc Surg. 2010;140:1276-82.

33. Robbins PF, Lu Y-C, El-Gamil M, Li YF, Gross C, Gartner J, et al. Mining exomic sequencing data to identify mutated antigens recognized by adoptively transferred tumor-reactive T cells. Nat Med. 2013;19:747-52.

34. Le DT, Uram JN, Wang H, Bartlett BR, Kemberling H, Eyring $\mathrm{AD}$, et al. PD-1 blockade in tumors with mismatch-repair deficiency. $N$ Engl J Med. 2015;372:2509-20.

35. Brahmer J, Reckamp KL, Baas P, Crinò L, Eberhardt WEE, Poddubskaya E, et al. Nivolumab versus docetaxel in advanced squamous-cell non-small-cell lung cancer. $N$ Engl $J$ Med. 2015;373:123-35.

36. Tran E, Ahmadzadeh M, Lu Y-C, Gros A, Turcotte S, Robbins $\mathrm{PF}$, et al. Immunogenicity of somatic mutations in human gastrointestinal cancers. Science. 2015;350:1387-90.
37. Gattinoni L, Klebanoff CA, Palmer DC, Wrzesinski C, Kerstann $\mathrm{K}, \mathrm{Yu} \mathrm{Z}$, et al. Acquisition of full effector function in vitro paradoxically impairs the in vivo antitumor efficacy of adoptively transferred CD8+ T cells. J Clin Invest. 2005;115:1616-26.

38. Klebanoff CA, Gattinoni L, Torabi-Parizi P, Kerstann K, Cardones AR, Finkelstein SE, et al. Central memory self/tumorreactive $\mathrm{CD} 8+\mathrm{T}$ cells confer superior antitumor immunity compared with effector memory T cells. Proc Natl Acad Sci USA. 2005;102:9571-76.

39. Crompton JG, Sukumar M, Roychoudhuri R, Clever D, Gros A, Eil RL, et al. Akt inhibition enhances expansion of potent tumorspecific lymphocytes with memory cell characteristics. Cancer Res. 2015;75:296-305.

40. Klebanoff CA, Scott CD, Leonardi AJ, Yamamoto TN, Cruz AC, Ouyang $\mathrm{C}$, et al. Memory $\mathrm{T}$ cell-driven differentiation of naive cells impairs adoptive immunotherapy. $J$ Clin Invest. 2016;126:318-34.

41. Sukumar M, Liu J, Mehta GU, Patel SJ, Roychoudhuri R, Crompton JG, et al. Mitochondrial membrane potential identifies cells with enhanced stemness for cellular therapy. Cell Metab. 2015;23(1):63-76.

42. Palmer DC, Guittard GC, Franco Z, Crompton JG, Eil RL, Patel SJ, et al. CISH actively silences TCR signaling in CD8+ Tcells to maintain tumor tolerance. J Exp Med. 2015;212:2095-113.

43. John LB, Devaud C, Duong CPM, Yong CS, Beavis PA, Haynes $\mathrm{NM}$, et al. Anti-PD-1 antibody therapy potently enhances the eradication of established tumors by gene-modified T cells. Clin Cancer Res. 2013;19:5636-46. 